\title{
De-Extinct Species as Wildlife
}

\author{
MARKKU OKSANEN \\ University of Eastern Finland, \\ Dept. of Social Sciences \\ TIMO VUORISALO \\ University of Turku, Dept. of Biology
}

\begin{abstract}
The concept of wildlife embodies two sources of controversy regarding de-extinct animals. First, the multifaceted dependence of these animals on humans; and second, the property rights to de-extinct animals. Both provide reasons for not counting them as wildlife. A subsequent question is, however, whether we should maintain this divide or allow the boundaries to blur. If we aim to maintain it, we end up trying to stop a process that is evolving rapidly and difficult to curb by legal means. If we relinquish these boundaries, we give up customary cultural models and related cultural practices. In biology, the divide between domestic and wild species is usually considered arbitrary and the degree of synanthropy (degree of association with humans) to present a continuum. Still, wildlife is normally defined through the notion of domestication: those animals that are not domesticated are wildlife. Deextinction turns the setting upside down: the de-extinct animals would normally be classified as domesticated, since they are generated by human action and could be owned as private property, but the problem is that they are not intended as domestic - de-extinct animals are ultimately created to be wildlife. Thus the concept of wildlife calls for refinement so as to allow their inclusion. We present a classification of animal species based both on their degree of synanthropy and the complex ownership issues. It appears that de-extinct species would probably initially represent species with a low synanthropy index but a high need for human care, but might later evolve into "real" wildlife in the strict sense of the term.
\end{abstract}

KEYWORDS: property; domestication; extinction; genetic engineering; animals; conservation; synanthropy 


\section{Introduction}

"After decades of wilderness, wildness has now become the guiding principle of conservation." So claims the US geographer Irus Braverman $(2015,227)$ in her book on interventionist conservation practices. In this article, we explore the wildness of animals that one might classify as wildlife in the twinkling of an eye, especially after experiencing the 3D runaway dinosaurs of Jurassic Park at the cinema. Nevertheless, as the film's reptile protagonists are human creations, the wildness of Jurassic Park creatures is despite their fierceness anything but obvious.

De-extinction, or the resurrection of extinct species, and their release from laboratories or other confined settings with the aim of setting up self-sustaining populations and restoring their historic habitats, is not the stuff of sci-fi writers alone. The idea has reached a point of maturity and has been taken seriously in academia and conservation professionals, despite many philosophical and practical reservations (see Oksanen \& Siipi 2014; Camacho 2015; Shapiro 2015; IUCN SSN 2016).

In this article, we study de-extinction in the light of the dichotomy between wildness and domesticity, a key historical distinction in animal classification. The idea of de-extinction rests on the assumption that the individuals brought into existence by genome engineering or selective breeding, or by the mixed deployment of such technologies, can be placed into a biological category that has been empty of living representatives for some period of time. For such animals, the concept of de-extinct species is applicable. The basic biological classification, or the recognition of species membership, albeit fundamental, is not the only kind of categorization traditionally made by humans. Animal classifications are manifold, repeatedly colored by inconsistencies and often dominated by practical interests: consider the dualisms between edible v. inedible, dangerous v. harmless and so on. It is clear that de-extinct animals would not qualify as production animals unless used in the production of substances or other benefits for humans. The same idea would apply to classifying animals as companions: sabertoothed tigers and cave lions would hardly be anyone's favorite pets (apart from ruthless dictators and oligarchs). A more likely scenario, especially in pioneering attempts at de-extinction that could be profit-driven or that simply seek to cover expenses, is that the animals would first be exhibit animals and that later on, should attempts prove successful, also trophy hunting could be allowed. However, as we see it, the not-forprofit aim is to create wild animal species that would supplement the currently vanishing faunal diversity. As Braverman $(2015,155)$ has pointed out, "Protecting a domesticated donkey or a dog is typically not considered conservation, precisely because it has 
nothing to with wild animals." This is, we assume, the very motive why IUCN considers the topic worthy of a multi-authored report (see IUCN SNN 2016). Considering the disagreements over in situ and ex situ conservation programs (Braverman 2015) and over the classification of bioengineered cross-breeds (Friese 2010), de-extinction is hardly a closed case.

Even if de-extinction fails to breed organisms capable of survival and reproduction in the wild, the idea still functions as a useful thought experiment that sheds light on the nature of species membership, animal classifications in practice and the idea of extinction (Delord 2014). This article can also be read as a hypothetical exercise, in which the protagonist is the idea of wildlife, not the animals of the fantasy world. Wildlife carries a powerful cultural imagery. The concept is not, however, philosophically or scientifically established, although it has played a role as a contrasting concept in considerations about the nature of human sociality, civilization and culture, as well as in the expression of prejudices, which, at worst, dehumanize those who are called "wild men", "beasts", or "savages" (see Fernández-Armesto 2007).

Unlike its counterpart "domesticity", "wildlife" has to a large extent been an essentially uncontested concept - frequently used but seldom scrutinized in all its aspects. ${ }^{1}$ Although "wildlife" may look like a natural norm and domesticity as an exceptional phenomenon requiring explanation, "wildlife" is also used as an economic and legal concept so as to define the property status of an object, as we will see later on. In this article, we are interested in articulating the received view of wildlife and applying it to animals whose existence is attributable to de-extinction techniques. ${ }^{2}$ The received

1 Analyses by Palmer (2010) and Peterson (2013) are important but focus on problematizing the dichotomy between domesticity and wildness.

2 There is, however, one major issue that defines the scope of our inquiry: Does "wildlife" cover both animals and plants, or animals only? The major general dictionaries in the English language offer both options. On the one hand, the Merriam-Webster Dictionary defines wildlife as "animals living in nature", while the Collins Concise Dictionary states that wildlife especially refers to fauna. On the other hand, the Oxford English Dictionary suggests definitions of wildlife that include plants. To avoid confusion, the key conservation law in the European Union - the Habitats Directive does not employ the concept of wildlife but "wild fauna and flora" (expressed in the formal heading of the directive: Council Directive 92/43/EEC of 21 May 1992 on the conservation of natural habitats and of wild fauna and flora). The legal categorizations can be of a rather technical nature as, for example, the US Endangered Species Act that excludes fish from the category of wildlife (Camacho 2015, 865). This article focuses on animals and uses the concept of wildlife in a narrower sense that excludes plants. Moreover, the resurrection of plants and their introduction into the wild raises questions that can be quite different from those of resurrecting animals, not least because 30,000-year-old seeds have already been regenerated (Yashina et al. 2014; see also Martinelli, Oksanen and Siipi 2014). 
view is adopted from legal and biological discussions that date back to the Roman law. These historically mediated dualisms and simplistic dichotomies are, however, unfruitful when we pursue a systematic understanding about, and develop legal regulation of, those biological varieties that are generated by humans such as the proxies of extinct species (Camacho 2015).

The article is divided into four sections. First, we look at the practice of deextinction and how it can be divided into three phases. Second, we discuss the concept of wildlife and argue that in addition to "being domesticated", property status is a key attribute of wildlife. Third, we mix these themes to understand how property rights relate to de-extinct animals. Finally, we examine some problems with the received view of wildlife and de-extinct species.

\section{Three phases of de-extinction}

To begin with, imagine that de-extinction projects prove successful and that scientists manage to create entities that share the genotype with species officially viewed as extinct. Because of their genetic qualities, these living beings appear to have a place in the biological taxonomy and one might even claim that they descend from individuals that have actually existed, even though their reappearance is human-assisted. One of the expressed motives of de-extinction activists, explicit in the focal term itself, is to increase biodiversity and variability in nature by cancelling out or reversing extinction. In this respect, de-extinction differs from synthetic biology, should the latter be understood as the intentional production of biological innovations, of something that has never existed before. ${ }^{3}$ From the biological perspective, the idea of reversing extinction is radical since extinction has ever since Darwin been considered the ultimate fate of any species or population (Darwin 1859; Raup 1991).

As long as this reasoning holds, the purpose of de-extinction is to be an innovative and developing tool on a par with established nature conservation methods. Moreover, the animals produced by means of de-extinction are non-domestic and count as wildlife. The objective of bringing about wildlife is explicitly stated, especially in those back-breeding projects that start from domestic individuals and strive towards their long-gone wild, untamed ancestors. In the 1930s, the notorious Nazi zoologists Lutz and Heinz Heck strived to resurrect the aurochs from existing breeds of cattle to create

3 Another but related issue is the individuality of the animals brought about by means of deextinction techniques. Are they "just unique individuals" with no historical precedents or can they be taxonomically linked with species described earlier? (See Delord 2014.) 
an Aryan cow; today the outcome is known as the Heck cattle. The subsequent proprietors of the cattle have continued the project by locating them in nature reserves, such as Oostvaardenplassen in the Netherlands, and have kept human influence on them to the minimum (Gremmen 2014). The question about the precise meaning of "minimum" has sparked a public debate that resulted in a policy of "reactive culling" - to save the animals from starving to death; that is, from cruelty (Kolbert 2012). The categorization of these animals designates human duties and responsibilities with respect to them. Should the animals be considered wild, nature would be allowed to take its toll and the evolutionary process would continue without human interference. If they were considered domestic animals, instead, they would have a special relationship with humans who would owe them care, protection and, in some cases, the humane endpoint in slaughter (Palmer 2010).

There are also other selective breeding programs, such as the Quagga Project (2015) in South Africa, which aims to bring back the quagga, a subspecies of the plains zebra. In this case, both the source and the target animals are wild as far as "wildness" is attributable to animals who are, and whose reproduction is, ultimately under human control. Even after the possible establishment of a self-sustaining quagga population, the managers would have to prevent the quaggas from hybridizing with ordinary zebras and keep the populations - or their genes - isolated from each other (Heywood 2013).

If breeding is not an option and de-extinction must rely on the development of genome engineering, there are many complications en route to the ultimate end. The point of departure is the possession of genetic material, either from living animals or extracted from well-preserved carcasses or bodily samples. For the revival of the woolly mammoth, for instance, the discovery of well-preserved and uncontaminated DNA, or ancient DNA (aDNA for short) in the paleobiological vocabulary, would be necessary. The technical details and hurdles of implementing genome engineering are communicated in many works (Shapiro 2015; Nicholls 2008). More critically, no matter what technique is employed, the resulting individuals might not be perfect or pure instances of the species. For example, the IUCN report rejects the possibility of de-extinction outright: “The term 'de-extinction' is misleading in its implication that extinct species, species for which no viable members remain, can be resurrected in their genetic, behavioural and physiological entirety." Instead of talking about de-extinct species, they use the concept of proxy: "Proxy is used here to mean a substitute that would represent in some sense (e.g. phenotypically, behaviourally, ecologically) another entity - the extinct form." (IUCN SSN 2016, 1.) In other words, the created individual is classified and associated with some representatives of an extant taxon. 
What we encounter here is a problem of classification. Consider some wellrehearsed examples. Genetically, a re-born quagga individual would be a plains zebra variation with specific coloration - therefore some talk about the Rau quagga in order to pay homage to its originator Reinhold Rau (Heywood 2013). The resurrected woolly mammoth, according to the most realistic scheme, would most likely be a crossbreed of the woolly mammoth and the Asian elephant, "a mammophant". In essence, the issues and the disagreements are quite similar to those related to whether the aurochs still exist in the form of domestic cattle or whether the wolf, should it be entirely wiped out, would survive and flourish in the form of the domestic dog - domestication is, after all, an evolutionary process in which humans participate. The distinction between the domestic dog and the wolf in particular is legally important and it overlaps the divide between wildlife and domestic animals. One may consider the controversies over the coyote-wolf(-dog) hybrids in North America (Morell 2016), the Australian dingo (Crowther et al. 2014) or the dog-wolf, a more cosmopolitan hybrid that may be legally eliminated. ${ }^{4}$

In some sense this discrepancy resembles the old debate on the essentialistic species concept according to which each species is characterized by its unchanging essence (eidos) and is therefore sharply separated from all other species (Mayr 1982). All those objects that share the same "essence" belong to the same species. Variation observed in nature is the result of imperfect manifestations of the eidos (Mayr 1982). Clearly, an essentialist might still consider a Heck cow or a mammophant as an aurochs or a mammoth, respectively, in spite of some genetic and phenotypic differences between them and the ancestral species. Interestingly, the currently popular phylogenetic species concept might share this view: if a species is defined as an evolutionary lineage that has maintained its genetic integrity with respect to other lineages, slightly genetically engineered de-extinct species or results of breeding programmes may still be considered members of the same lineage.

\footnotetext{
4 In January 2013, three wolves were killed without a permit in Perho, Finland; the poachers were caught and sued. The poachers defended themselves in court by arguing that they had only eliminated dog-wolf hybrids and had thus not breached the law. In November 2015, the Vaasa Court of Appeal decided that the killings were not justified, even though, based on genetic analyses, the three killed wolves belonged to the wild Finnish wolf population with the likelihoods of $97.3 \%$ to $99.3 \%$. (VaaHO:2015:14 available at: https://oikeus.fi/hovioikeudet/vaasanhovioikeus/fi/index/hovioikeusratkaisut/hovioikeusratkaisut/1447917399092.html [Accessed 18 December, 2015].) From the biological perspective, such exact percentages are arbitrary due to wide intraspecific genetic variation; it may also be pointed out that $1.5-2.1 \%$ of non-African modern human DNA comes from Neanderthals (Wong 2016). Still we consider ourselves modern humans.
} 
Besides the technical and philosophical uncertainties, there are also ethical issues concerning the development and application of de-extinction techniques. Prominent animal ethics theorists, both in the Kantian (Regan 1988) and the utilitarian (Singer 1979; 2010) traditions, are highly disapproving of the experimentation with animals. Regan's theory of animal rights has called for a total ban on experimentation that involves sacrificing individuals for meeting the interests of others. For the utilitarians, the use of sentient animals in painful experiments is acceptable as far as it can be reasonably expected that the benefits override the welfare losses to animals. It is, however, difficult to see how reviving extinct species would benefit the animals themselves. These widely espoused ethical views can stop de-extinction from becoming reality. The technical and philosophical issues form the first phase of the study of de-extinction, to follow the two-phase separation made by Beth Shapiro (2015).

Let us ignore these imperfections and qualms of phase one for the sake of fleshing out other de-extinction issues. The second phase of de-extinction embraces the creation of living, healthy and fertile individuals capable of producing offspring with similar capabilities. Shapiro says that, "Ideally, this second phase would culminate with the establishment in the wild of multiple genetically robust, healthy, self-sustaining populations that are resilient in the face of environmental change" (Shapiro 2015, 1689). She goes on to examine the problems that stem from setting free captive animals and from how they learn to cope with new environments. There are plenty of examples of managed introductions, relocations, and accidental releases of different species in different circumstances. Animals in successful (re)introductions are not particularly vulnerable to shortcomings or dependent on human aid. However, the data gathered from the releases of captive-born individuals is not encouraging (Jule et al. 2008). By and large, the estimates for reintroduction success vary between 10 and 38 percent (Braverman 2015, 131). In general, we cannot know without experimenting whether de-extinct animals are capable of forming self-sustaining populations or not.

Since de-extinct animals would be genetically modified or their genome reconstructed, there would be serious legal obstacles to their release into the wild. Although animal experimentation for biodiversity conservation purposes can be allowed (the decision is at the discretion of the public authorities), in the majority of legislative systems the intentional release of genetically modified animals is strictly regulated, if not unconditionally banned (see Reeves et al. 2012). However, the question of what a release means is problematic: does it mean setting an animal free outside the laboratory or outdoors but within a confined area or, as broadly as possible, unlocking all physical barriers that might hinder free movement? It is apparent that the free roaming of de- 
extinct animal populations would not be allowed on the spur of the moment, and their populations would likely be managed by humans in facilities to which the public could buy tickets: expenses have to be covered, after all.

Let us leave behind the phase two problems and obstacles. Shapiro's distinction between the two phases is inadequate and a third phase should be recognized. In this phase, when we have or are about to have (or just speculate about having) de-extinct animals, we face decisions about the normative status of a new type of living individuals. Some of the issues are similar to those faced in phase one over the moral acceptability of animal experimentation and over morally relevant capacities of individuals. On the other hand, if de-extinct animals are somehow brought into existence, perhaps illegally or against basic ethical principles, the individualistic animal ethics tends to prioritize their freedom from human influence and endorse a non-interventionist approach in which the key obligations are negative: do not hurt, do not kill, do not capture, and so on.

It is, also, important to define these novel animals culturally and legally: How do they relate to humans and other animals? What is their place in the collective experience of human societies? There are many ways to classify animals but the most important divide is between domestic animals and wildlife, a divide that is often thought of as fundamental. In particular, the starting point of Roman law and, more broadly, of the Western legal understanding of animals is that "all animals are either wild or domestic", as the British legal scholar D.I.C. Ashton-Cross $(1953,395)$ bluntly began his article. The concepts of domesticity and wildlife are intertwined with property concepts. As Ashton-Cross underlined, domestic animals are normally private property while wildlife is not. ${ }^{5}$ The emphasis here is on the word "normally" - there are a lot of exceptions.

In general, the introduction of de-extinct animals into their assumed natural habitat not only requires but also results in a process in which the cultural, social and legal position of animals is explicated at various levels: locally, nationally, and globally. One of the trickiest problems is the fundamental divide between domestic and wild animals, since these categories imply different value considerations. Next, we turn to shedding light on the received view of wildlife.

5 More recently, echoing the ancient idea of the political and public life of humans, Will Kymlicka and Sue Donaldson $(2014,5)$ have applied citizenship theory to animal ethics. Domesticated animals are like citizens in ordinary political theory. One of the rights of domesticated animals is the right to residency that disallows the expulsion of domestic animals from a human community: rewilding is not something to which these animals should be exposed. 


\section{Wildlife understood traditionally}

What we call the received view is a constructed simplification that is based on certain historical sources. We will base our construction on three kinds of source material: natural history, anthropological studies as well as political and legal discussions and documents (cf. Russell 2002). (Of course, other sources such as representations of animals in visual and literary art and folklore are important but they remain outside the scope of our analysis.) The received view on wildlife is dichotomic in essence. The dichotomy means that animals are considered either entirely wild or entirely domestic; traditionally, positions between "wild" and "non-wild" or "domestic" have been conceptually less specific and established. Many animal populations do not, however, belong to either class but are and should be positioned somewhere between the extreme ends of the continuum, as Peterson (2010) pointed out. Consider as examples the dog-wolf hybrids in the wild, lions farmed for trophy hunting in fenced properties in South Africa, the freely breeding Heck cattle, or the so far imaginary re-created quagga. Also in anthropology an emerging trend has been to challenge simplified models and ideas on interaction between humans and animals (see Harris 1996; Cassidy and Mullin 2007). The property dimension has been "de-emphasised" because of its one-sided focus on human control over non-humans (Cassidy 2007, 2). ${ }^{6}$ Another thing to notice is that the traditions occasionally intersect each other. The Finnish legal case of defining wildlife crimes, which was mulled over above, is a case in point: the wolf poaching case represented a mixture of layperson perceptions and behaviors, genomic analysis and juridical deliberation.

A diverse terminology concerning this continuum is used in the study of animals in cultural landscapes. In his pioneering book on urban ecology, the German zoologist Bernhard Klausnitzer (1988) classified animals into those that benefit from and are attracted by cultural influence (Kulturfolger), to those that avoid cultural influence (Kulturflüchter), and to species indifferent to cultural influence (Kulturindifferente). In the English language species that profit from anthropogenic change are called hemerophiles (synonym of Kulturfolger) and those that do not are called hemerophobic (Kulturflüchter). A particularly useful concept for our discussion is synanthropy, which

6 The negligence of property concepts reflects a conception of ownership in which ownership is a relationship between the owner and the property object, and in which the owner dominates objects. In the Western political and legal thought, property is by contrast understood as a relationship between people in regard to property objects, and owning something is to have the greatest protected interest in that object, as against the claims of other people. (See Oksanen, forthcoming.) 
in the strict sense refers to so close an association with the human habitation that even the original natural habitat of synanthropes may be unknown. The concept has been traditionally used for both plants and animals. Klausnitzer (1988) made a clear distinction between synanthropes and domesticated species; the former are not actively kept or supported by humans while the latter are. Well-known synanthropes are the house sparrow and pest species such as brown rats or house mice. House sparrow, for instance, is only known from human habitations (Summers-Smith 1963).

The degree of synanthropy also represents a continuum. Klausnitzer (1988) proposed a classification of synanthropy into five categories (Table 1). Categories in Table 1 are not mutually exclusive. The categories of permanent, temporary and partial synanthropy refer to (in this order, decreasing) temporal dependency of populations to anthropogenic habitats, while the categories of obligatory and facultative synanthropy refer to the degree of intraspecific variation in the synanthropy level. The word "obligatory" in the ecological context is not normative, but refers to total dependency on human habitations. In obligatory synanthropes all known populations only live in association with human habitations either permanently, temporarily or partially. Facultative synanthropy allows intraspecific variation in this respect so that some populations may even exhibit no synanthropy at all.

Obligatory synanthropy

Facultative synanthropy

Permanent synanthropy

Temporary synanthropy

Partial synanthropy
Species only lives in anthropogenic habitats.

Often cosmopolitan.

Anthropogenic habitats are optimal for the species, but it also occurs elsewhere.

Species that spend their entire life-cycle in anthropogenic habitats.

Species that live only seasonally (e.g. in winter) or under other specific circumstances in anthropogenic habitats.

Species that regularly live but only for a certain purpose (e.g. nesting) in anthropogenic habitats.

Table 1: Klausnitzer's (1988) classification of synanthropy. 
The Finnish entomologist and environmentalist Pekka Nuorteva (1963) presented a synanthropy index to measure quantitatively the degree of preference for human settlements by a particular species, and applied this quantitative measure to his studies on insects (Nuorteva 1963) and urban birds (Nuorteva 1971). The value of Nuorteva's synanthropy index is based on species' habitat preferences and ranges between +100 and -100 , the former representing the highest degree of synanthropy (i.e. a species wholly dependent on human habitation but not actively supported by man; Nuorteva 1963). Nuorteva clearly used synanthropy in a wider sense than Klausnitzer (1988); still both would agree that genuine synanthropes represent only one end of a continuum.

By and large, the concept of wildlife expresses something similar about human relations to animals as the concept of wilderness about human relations to the rest of nature. There are, of course, many ways to define wilderness but often those areas where the human influence is minimal are considered places of wilderness. Conspicuously, the words "wildlife" and "wilderness" share the etymological root denoting wild animals ("wild deer", more precisely, according to the Oxford English Dictionary) and their habitats outside human settlements. Wildlife does not comprise all animals that exist and wildlife does not merely live in designated wilderness areas. Wildlife is not place-tied but can occur anywhere, including uninvited guests indoors that Klausnitzer (1988) would in most cases classify as obligatory and permanent synanthropes (see Table 1). In many biological dictionaries, the emphasis is on the undomesticated nature of animals. So, any animal that is not domestic(ated) belongs to wildlife. In this approach, the concept of domesticity and the nature of domestication as a process is at stake.

The Oxford Encyclopedia of the Modern World has an entry "wildlife" that begins quite differently: "In 1750, wildlife in much of the world was considered a natural resource to be exploited. Exploitation was governed by various customary and codified laws ranging from sacred groves in India to laws like the British Game Act of 1831, which regulated the hunting of wild animals." (Strahorn 2008.) This definition leads to an entirely different direction in which human relations and, in particular, property relations come to the fore, and wildlife is of value as a resource base that authorized people can harvest. As David Favre (2010) puts it, "the legal system has presumed that wildlife are available for use and consumption by humans, thus their lower legal status as 'things'."

Many Western political and legal thinkers who have focused on ownership have explained the nature of resources that remain outside property arrangements. One of the most influential was the Dutch legal thinker Hugo Grotius, whose classic text Mare Liberum (1609) compared wildlife (i.e. wild beasts) with the sea and the air that are, as he claimed, non-property. He wrote: "Therefore the proximate reason why the sea 
cannot be possessed is neither its fluid nature nor its 'continually flowing to and fro' [...] but its incomprehensibility, the same as in the case of the air. Meanwhile that vigorous motion of the sea, as the untamed instinct in wild beasts, would make it impossible, even if occupation took place here, for possession to be continued, and ownership through possession, unless by a perpetual and close guardianship." ${ }^{7}$ However, taming of the "wild beast" makes its exclusive ownership possible - but only if it is domesticated, to interpret "perpetual and close guardianship" in modern terms.

In the common law tradition, Favre $(2010,463)$ provides the following definition of wildlife in which the element of domestication is not explicit: "Animals living in their natural habitat and not within the possession or control of humans." Thus there are two qualitatively separate components: the place of living component, and the ownership component. The notion of the natural habitat - apparently in most cases - refers to a place other than human buildings and their immediate surroundings (domus). Actually, it is rather difficult to think about domestication and domestic animals without thinking about whom they belong to. Therefore, it is ironic that so often the analyses of domestication are approached merely as an enigmatic natural phenomenon that requires explanation and more seldom as a societal issue, although the concept of "domestication" explicitly denotes household and thus human interference. Domestic animals without a named owner are often classified differently from captured untamed animals turned into escapee animals; the attributes of "feral" and "stray" are ascribed to them (Table 2, Category B). Therefore, the legal characterizations of wildlife tend to be more complex, reflecting the contextual ethics that Palmer (2010) has explicated and defended. According to it, the right and the wrong in the human treatment of animals do not merely depend on the animals' intrinsic qualities but also on the larger context of action and the position of the animals in the web of relations with and between humans.

\section{Ownership issues regarding de-extinction}

When it comes to the ownership component, there are several options. In the Western cultural context, wildlife is not personal or private property but is rather owned by the state (e.g., the state/public ownership doctrine in the USA), by local communities (e.g., jointly managed fisheries), by nobody, or by everybody (the wildlife outside national

7 In times of Grotius, the idea of transferable fishing quota was probably not known, although studies on the customary laws and traditional local resource systems controlling use and access to the resource base have uncovered that their history can be much longer than often expected. See e.g. Ørebech et al. (2005). 
economic zones, such as penguins in Antarctica). The utilization rights to wildlife can be universal and unrestricted (consider high-sea fisheries outside economic zones) although in most cases, with the exception of fishing, they are regulated or tied to land ownership. According to non-private or shared ownership of wildlife, wildlife forms a kind of resource base that can be utilized and no one can make exclusive property claims into it as long as the resource base remains shared. The implementation of legal rules for sustainable use and the prevention of overharvesting is a key issue of conservation. Because of implementation problems, communal ownership that is strictly regulated by members of the community has been proposed as an alternative (Ostrom 1990). In some cases, communal ownership shares some characteristics with private ownership while in other cases it does not. In addition, relationships between different normative systems vary and tend to be complicated. Therefore, generalized statements whether a communitycontrolled bio-resource qualifies as wildlife tend to be unseaworthy: ready to sink when undocked. The state can be a disinterested owner of wildlife in various ways, for example by not striving for maximizing returns, by not aiming to save the species by means of legal protection, or by not sanctioning law properly so as to prevent poaching (which is an instance of failure of ownership). Wildlife according to the state ownership doctrine is comparable to the Lockean understanding of wilderness or the state of nature at least in this respect: whereas the hunter is the owner of the prey through the act of hunting, the land becomes a property by mixing one's labor with it and thus transforming it from the state of nature to the state of cultivation. ${ }^{8}$ The starting point in both cases is the resource being outside the (enforced) property arrangement.

In the current Finnish legislation, although the term "wildlife" (luonnonvarainen" in Finnish; vilda djur in Swedish, the second official language) is habitually used, it is not precisely defined in the relevant laws, such as the Animal Welfare Act, the Nature Conservation Act, or the Hunting Act. ${ }^{10}$ It is likely that the legislators wanted to avoid some of the problems stemming from the use of "wild" in vernacular concepts, and therefore the

\footnotetext{
8 See John Locke's Second Treatise of Government, 1680, esp. chapter Of Property.

9 The category of luonnonvarainen branches further. Game animals (riistaeläimet) are included in the category of luonnonvarainen. Villieläin, the literal translation of vilda djur, is also used in colloquial language referring to large non-domestic animals primarily. It parallels with "wild beast" in English (at least in some contexts).

10 There is, however, a notable dissimilarity: The Swedish vilda djur literally means "wild animals", but Finnish luonnonvarainen is formed differently: It means "living on nature", free from human support and care. Thus it is reminiscent of the concept of autarky (gr. autarkês). In its Aristotelian sense, autarky means self-sufficiency, but Meikle (1995) proposes two other meanings for it: "having enough" and "being independent of others".
} 
Animal Welfare Act explicitly covers all animals independently of their position in Finnish culture and society. Moreover, there is no definition of the kind that Favre $(2010,436)$ offers on wildlife: "Animals living in their natural habitat and not within the possession or control of humans." We reckon, in any case, that Finnish legislation and legal practices follow, by and large, the received view expressed by Favre, as do most Western legislative systems that rest on the Roman law. Genuine wildlife is not appropriated wildlife since no one has mixed their work with it; thus it lacks the foundational element of the title claim. The Finnish concept of luonnonvarainen comes close to Favre's application of the libertarian notion of self-ownership to animals as against the public or state ownership doctrine. He writes, "As a wild animal, the squirrel of Yellowstone is not yet human-controlled; she retains self-direction, self-control and self-ownership. It is a misperception of existing property law to say that title is in the state when wildlife exists in its natural environment. If no human or human substitute has possession and control over a wild animal, there cannot be an assertion of title." (Favre 2000, 473.) Thus, ideally, the wildlife owns itself. In practice the situation is often more complex. The aforementioned Finnish wolf poaching case demonstrates the types of problems that may emerge. An ordinary dog is obviously a private property (since there are virtually no feral dogs in Finland), and the wolf is a property of the state in the sense that culling of wolves requires an official permit. $A$ hybrid dog-wolf, instead, has a contentious status since its "species purity" is difficult to verify. Theoretically, it represents a kind of "living biological outlaw" whose status would require clarification on a case-by-case basis.

The prerequisite for the realization of de-extinction procedures is the possession of animal genetic material, the access to relevant technologies, and the permission to use it in the living animal models or proxies. The animal genetic material is matter that can be owned as any other tangible stuff, unless the ancient DNA (aDNA) is considered as an archeological relic of special concern and thus the subject of governmental protection. In many cases, the discoverers are the owners and the objects containing aDNA are ordinary commodities to be bought and sold at the marketplace. Just think about the traditional trade in mammoth bones, nowadays handled on the internet. ${ }^{11}$ When it comes to aDNA as genetic information, we enter the domain of intellectual property and there we meet great variance in legislative systems. The common question concerning patentability is whether the aDNA in its examined form is a human artifact or a product of nature: only the former is patentable. This is a highly controversial issue since all we have is this aDNA and obviously we cannot compare it with something

11 See e.g., http://www.boonetrading.com/Mammothlvory.html [accessed December 17, 2015]. 
that is unquestionably a product of nature. It is also common to legislative systems to acknowledge that DNA is animal genetic material that can be used in the creation of lineages of living animals. In the United States, there are no morality provisions in regard to patentability, and so, in principle, modified genetic material can be protected by means of intellectual property rights (provided it meets the other conditions of patentability). In the EU, where the European Patent Convention (EPC) is the fundamental treaty on these issues, patents cannot be granted for animal varieties. Nonetheless, in the famous case of the oncomouse, a genetically modified mouse, the European Patent Office granted a patent because it did not consider the oncomouse a biological variety and because granting patent protection to the oncomouse is likely to benefit the medical sector and the rest of society. ${ }^{12}$ In Canada, the Supreme Court rejected the patent application for the oncomouse. All in all, it is difficult to predict how patent applications for the resurrection of the woolly mammoth might be solved under different jurisdictions.

The oncomouse is a laboratory animal whose life is as tightly controlled as life can be. It would be very unlikely to survive if released into the wild. Moreover, its (humanassisted) reproduction is regulated by patents. The received view of wildlife is agnostic about animal patents, but when patenting is regarded as a form of exclusive ownership, as it customarily is, creatures like the oncomouse do not fall within the category of wildlife because of patents. A genomically engineered mammoth shares transgenicity with the oncomouse, but the ultimate objective is to make the mammoth wild by bringing into existence fertile individuals that survive and breed on their own and may constitute self-sustaining populations. Would it still belong to wildlife even if patents were granted for the processes of creation or for the genetic material? On the face of the received view on wildlife, transgenicity, human-assisted reproduction, and patents make such an animal being devoid of elements that are required of wildlife. However, if it were not wildlife in the sense of natural wildlife, the necessary condition for patentability could be met. The role of intellectual property rights is ambiguous. On the one hand, they reflect deep human control over animal life; on the other hand, these rights may not necessarily determine the course of life of individual animals in the same sense as domesticity does.

The phase two ownership issue is fundamentally about the right to flesh-andblood animals earned through transactions or through breeding and raising the animal. (The ownership of these animals could be conveniently justified in terms of the labor theory of property acquisition.) According to this line of thought, de-extinct animals

12 https://www.epo.org/law-practice/case-law-appeals/recent/t900019ep1.html [accessed December 30, 2015]. 
are living individual animals that are tangible property objects, or chattel. They can be acquired, used, and sold. In other words, they are things. In addition, animals in different kinds of enclosures, like in zoos, wildlife parks and fishponds, are objects that belong to their owners even though they are essentially untamed and thus wild by their nature. Since the development of Roman law, Western legislation has adopted highly sophisticated means to address problems stemming from the ownership of domestic and captured animals. It is tricky to say anything universally valid about the legal status of escapee animals; it depends on the species and country and other details. However, it is very likely that the owners will control the reproduction of these animals and therefore they hold a lower position as wildlife.

Assuming that de-extinct animals will be ultimately set free, we might have to consider their hunting. If they were privately produced and reproduced, their DNA would be patented and their wildlife status hence dubious, so it is hard to see how there could be any regulation on their use other than the general animal welfare legislation. Since general animal welfare legislation does not disallow the killing of animals, there can be hunting of de-extinct species as soon as their populations are dense enough to tolerate it. In such a situation, the developers of de-extinct animals might want to establish a regulatory system that would allow them to sell hunting licenses to the highest bidder or otherwise help them to maximize the returns of their investments. If de-extinct animals remained in confined settings, the prospect of them being commodities, either in the form of exhibit animals or zoo animals, would not be far-fetched. In such a situation, the commodification of de-extinct animals would be quite different from how we think of them as wildlife; to paraphrase Tom Regan, commodification and wildlife are like oil and water -- they do not mix. Once again reality would differ from the ideal world. Even if there could not and should not be privately-owned wildlife, there always is - both legally and illegally.

The laws concerning possession of exotic, often wild animals vary within the bounds of international wildlife laws, such as the Convention on International Trade in Endangered Species of Wild Fauna and Flora (CITES). In our own country, Finland, Animal Welfare Act disallows the taming of species classified as wild - the law is however limited to mammals and birds (Animal Welfare Act, section 13). Exotic animals tend to be treated differently and might not be listed in domestic law. Moreover, the domestication is an ongoing process and results in the expansion of the category of domesticated birds, for instance, under the heading of poultry. Consider as an example the brief history of ostrich as poultry. Over 150 years, ostrich farms have popped up in habitats that are far from the historic range of the species. This African species now 
lives in farms close to the Polar Circle. ${ }^{13}$ Likewise, the Arctic fox is kept as a fur animal but is renamed as the blue fox. In the USA, the possession of exotic, wild animals as pets is regulated at the state level. The impact of regulation can be seen, since in National Geographic's report in April 2014, it was estimated that "more exotic animals live in American homes than are cared for in American zoos"14; although the trend is towards a more harmonized regulation within the United States (Favre 2010, 1066-67). Native wildlife can also be privately owned. If we leave aside zoos, there are wildlife parks in which native animals roam and reproduce freely. They qualify one criteria of wildlife, but not the other. In general, there is so far no regulation specific to de-extinct animal trade.

\section{Concept of wildlife - some second thoughts}

Our main thesis has been that the concept of wildlife embodies two sources of controversy regarding de-extinct animals: first, the multidimensional ontological and biological dependence of these animals on humans; and second, the property rights to deextinct animals - independently of the type of property, whether property in terms of animals is tangible or intangible.

Neither of them provides reasons for not counting de-extinct animals as wildlife sensu lato. A subsequent question is, however: should we maintain the divide between domestic and wild animals or allow the boundaries to blur? If we aim to maintain it, we end up having a simplified view of animal-human relations and their regulation, and we might try to stop a process that is evolving rapidly and is difficult to curb by legal

13 The ostrich was an economically valuable source of meat, eggs, leather and feathers but the wild populations were decreasing. So, there was a commercial rationale for the ostrich conservation - conservation here meaning the sustainable use of the species (cf. Hays 1999). In the early 1990's, this rationale was more widely used in the emerging biodiversity discourse. For instance, E. O. Wilson began to speak about "a revolution in conservation thinking", about "New Environmentalism" that has shifted the focus to "the practical value of wild species" that, he assumes, could "give the invisible hand of free-market economics a green thumb". (Wilson 1994, 270-71.) His proposal on the utilization of Amazon river turtles is indicative of this tactics: "The seven known species [of the genus Podocnemis] are highly regarded as a protein source by local people. The meat is of excellent quality and the base of a pleasing native cuisine. As the river banks have been more thickly settled, the turtles have been overhunted and several species are now endangered. But they are also easy to cultivate. Each female lays a clutch of up to 150 eggs, and the young grow rapidly. One species, the giant Podocnemis expansa, reaches a length of nearly a meter and a weight of 50 kilograms." (Ibid., 282.) Seeing such utilities in wildlife (ecosystem services) and aiming at their conservation raises questions about the consequences to their wildness and wildlife character.

14 http://ngm.nationalgeographic.com/2014/04/exotic-pets/slater-text; a list of exotic pet animals: https://en.wikipedia.org/wiki/Exotic_pet [accessed July 1, 2015]. 
means. If we relinquish these boundaries, we give up customary cultural models and related cultural practices. There are, however, scholars who see the transgression of established boundaries as a good direction to follow (Peterson 2013; Braverman 2015; Camacho 2015). In addition, the individualistic animal ethics is highly dubious of the conventional classification of animals: what matters is the morally relevant, non-relative qualities of individual beings.

In biology, and especially since Darwin's Origin of Species, the divide between domestic and wild species has probably always been considered arbitrary, and the degree of synanthropy to present a continuum. In Table 2 we have presented a classification of species based on their degree of synanthropy, and simultaneously taking into account the complex ownership issues. It is obvious that de-extinct species, if ever realized, would in most cases fall into Category $C$. In the long run, if viable permanent populations of de-extinct species could be established, they might move into Category A that represents wildife sensu stricto.

\begin{tabular}{|c|c|c|}
\hline & Synanthropy (index) & \multirow[b]{2}{*}{ High } \\
\hline & Low & \\
\hline \multirow[t]{2}{*}{ Low } & A Wildlife s. str. & $\begin{array}{l}\text { B Feral species, human } \\
\text { commensals, pests }\end{array}$ \\
\hline & Public ownership? & "Anti-property" \\
\hline \multirow[t]{2}{*}{ High } & $\begin{array}{c}\text { C Threatened species, } \\
\text { de-extinct species }\end{array}$ & $\begin{array}{l}\boldsymbol{D} \text { Domesticated species } \\
\text { that need management }\end{array}$ \\
\hline & Public/private ownership & Private ownership \\
\hline
\end{tabular}

Table 2. Classification of species based on their degree of synanthropy (Nuorteva 1963, Klausnitzer 1988) and need of human care. The term "anti-property" in Category B refers to the fact that feral species and other human commensals are usually classified as pests, or as a threat to real property, with an obligation to persecute them if possible. 
It is obvious that de-extinction of animals blurs some established boundaries that have played an important role in law and in the cultural understanding of animals. However, the new world is full of paradoxes: Wild animals as property items, or as things; wild animals with a history in which humans were generators; or domestic animals that are wild and free within confines, new species being the subject of cultural evolution and perhaps of domestication, and old species being de-domesticated or rewilded. The lines of demarcation are controversial and there is a kind of continuous tendency to transgress the existing systems of classification. This causes trouble for legal regulation and its enforcement that might be solved to some extent by rejecting the dichotomy between wildlife and domesticity. This is, however, easier said than done.

The idea of the received view on wildlife as presented above is a simplification. Even in the ancient Roman law there were living animals that were wild but owned by individuals - consider, as an example, circus animals that were captured, transported and ultimately killed in a fight. They were quite different from the dogs and cocks that were bred to have good fighting qualities. Thus the term wild did not merely express the position of an animal in the system of ownership as a non-property. In other words, the concepts of non-property and wild are not synonyms, since wildness also refers to undomesticated nature.

\section{Concluding remarks}

Our question was whether de-extinct animals should be classified as wildlife or whether they are doomed to present a permanent anomaly, a category of unidentifiable "bioobjects" (Martinelli, Oksanen and Siipi 2014) due to their intricate and deep relationship with humans, particularly through property relations, despite the fact that they possess undeniable characteristics of wild animals. Independently of its realization, de-extinction offers a unique opportunity to focus on the concept of wildlife.

"Wildlife" is habitually defined in terms of domestication: non-domesticated animals are called wildlife. In environmental ethics, many scholars have emphasized the value of nature and wild animals that are independent of humans and therefore authentic, or natural, in the various meanings of the terms. The possibility of de-extinction confuses the traditional conceptual setting: although de-extinct animals would normally be classified as domesticated since they are generated by human action and could be owned as private property, they are not meant to be domestic - instead they are primarily created as future wildlife. The concept of wildlife thus calls for refinement so as to allow their inclusion. We have presented a conceptual model that makes it possible. 
Does it matter if de-extinct animals are not wildlife? We have defended the claim that it does. Consider if mammophants and other similar beings were categorized in the way that dog-wolf hybrids (in the wild) are at present - if gone feral, killing of them on encounter might be socially desirable but not legally justified. The laws and guidelines that encourage the monitoring and administering of purity of animal populations will be in trouble if hybridity becomes a norm and the demarcation line between wild and domestic animals is dissolved. It is clear that if mammophants and others are brought to life, they will be extremely valuable not only scientifically but also economically. They would not be open-access game animals for a long time, but since there are people who can and are motivated to pay huge sums for unique prey animals, venture entrepreneurs would likely see some business opportunities there. The category of mammophants might become a new category that serves different and possibly conflicting interests. It should be remembered, after all, that the classification of animals and other biological beings is never independent of human concerns and non-scientific interests.

Phase one problems are largely scientific and technical in kind; phase two problems would be more a mixture of scientific, technical, and social problems. The social problems here refer to the social responses from local communities: would newcomers be accepted or not? Phase three problems are legal and ethical and arise from the fact that legal categories for de-extinct animals do not yet exist; these animals would be sorts of anomalies, falling somewhere between the extremes of domestic animals and 'genuine' wildlife, the two ends of the synanthropy continuum. If de-extinct animals came into existence, we think it would be rather realistic to imagine them being designated as things in the ordinary legal sense of property law; they might also be trademarked and their production or the animals themselves might be protected by patents. Moreover, they would be bioengineered animals in the wild and so in some novel sense also wildlife. It is difficult to predict the possible role of de-extinct animals as a resource in the traditional sense of the term. It is equally difficult to consider that de-extinct animals, particularly the slowly reproducing kinds, would be neglected - as precious animals they would be most likely carefully looked after.

In concentrating on de-extinct animals, we have assumed that they would somehow bring profit to their owners. We have not touched upon an issue that was elemental to Roman legal considerations regarding animals: liability for the damage and injuries caused by animals. Roughly, liability is related to ownership, and injuries caused by wildlife owned by no one are no one's fault. Bearing in mind the fictive story of Jurassic Park, views on the allocation of accountability and risk management are also elemental for the future acceptability of de-extinction. 


\section{ACKNOWLEDGEMENTS}

We would like to thank Tua Korhonen and Anne Kumpula as well as the two anonymous referees for their comments. Earlier versions of the article were presented at ISHPSSBconference in Montreal (July 2015) and at YHYS-colloquium in Tampere (November 2015).

\section{REFERENCES}

Ashton-Cross, D.I.C. 1953. "Liability in Roman Law for Damage Caused by Animals." Cambridge Law Journal 11: 395-403.

Braverman, I. 2015. Wild Life. The Institution of Nature. Redwood City, CA: Stanford University Press.

Camacho, A.E. 2015. "Going the way of the dodo: De-extinction, dualisms and reframing conservation." Washington University Law Review 92: 849-906.

Cassidy, R. 2007. "Introduction: Domestication Reconsidered." In Where the Wild Things Are Now: Domestication Reconsidered, edited by Cassidy, R. and M. Mullin, 1-25. Oxford: Berg.

Cassidy, R. and M. Mullin (eds.). 2007. Where the Wild Things Are Now: Domestication Reconsidered. Oxford: Berg.

Hays, S.P. 1999. Conservation and the Gospel of Efficiency. Pittsburgh: University of Pittsburgh Press.

Crowther, M.S., M. Fillios, N. Colman and M. Letnic. 2014. "An updated description of the Australian dingo (Canis dingo Meyer, 1793)." Journal of Zoology 293: 192-203.

Darwin, C. 1859. The Origin of Species. London: John Murray.

Delord, J. 2014. "Can We Really Re-create an Extinct Species by Cloning? A Metaphysical Analysis." In The Ethics of Animal Re-creation and Modification Reviving, Rewilding, Restoring, edited by M. Oksanen and H. Siipi, 22-39. Houndmills: Palgrave.

Favre, D. 2000. “Equitable Self-Ownership for Animals.” Duke Law Journal 50: 473-502.

Favre, D.S. 2010. "Wildlife Jurisprudence." Journal of Environmental Law and Litigation 25: 459-509.

Fernández-Armesto, F. 2007. So You Think You're Human? Oxford: Oxford University Press.

Friese, C. 2010. "Classification conundrums: Categorizing chimeras and enacting species preservation." Theory and Society 39: 145-172. doi: 10.1007/s11186-009-9103-7 
Gremmen, B. 2014. "Just Fake It! Public Understanding of Ecological Restoration." In The Ethics of Animal Re-creation and Modification Reviving, Rewilding, Restoring, edited by M. Oksanen and H. Siipi, 134-149. Houndmills: Palgrave.

Grotius, H. 2004. The Free Sea, with William Welwod's Critique and Grotius's Reply. Trans. Richard Hakluyt. D. Armitage (ed.), Indianapolis: Liberty Fund. (Originally published 1609.) http://oll.libertyfund.org/titles/859. Accessed December 17, 2015.

Harris, D.R. 1996. "Domesticatory Relationships of People, Plants and Animals." In Redefining Nature. Ecology, Culture and Domestication, edited by R. Ellen and K. Fukui, 437-467. Oxford: Berg.

Heywood, P. 2013. "The Quagga and Science: What Does the Future Hold for This Extinct Zebra?" Perspectives in Biology and Medicine 56: 53-64. doi: 10.1353/ pbm.2013.0008

IUCN SSC. 2016. IUCN SSC Guiding principles on Creating Proxies of Extinct Species for Conservation Benefit. Version 1.0. Gland, Switzerland: IUCN Species Survival Commission. https://portals.iucn.org/library/sites/library/files/documents/Rep-2016009.pdf. Accessed October 25, 2016.

Jule, K.R., L.A. Leaver and S.E.G. Lea. 2008. "The effects of captive experience on reintroduction survival in carnivores: a review and analysis." Biological Conservation 141: 355-363.

Klausnitzer, B. 1988. Verstädterung von Tieren. Wittenberg Lutherstadt: A. Ziemsen Verlag.

Kolbert, E. 2012. "Recall of the Wild: The quest to engineer a world before humans." The New Yorker, December 24, 2012. http://www.newyorker.com/magazine/2012/12/24/recall-of-the-wild. Accessed September 2, 2016.

Kymlicka, W. and S. Donaldson. 2014. "Animals and the Frontiers of Citizenship." Oxford Journal of Legal Studies 34: 201-219. doi:10.1093/ojls/gqu001

Locke, J. 1988. Two Treatises of Government. Peter Laslett (ed.). Cambridge: Cambridge University Press (originally published 1690).

Martinelli, L., M. Oksanen and H. Siipi. 2014. "De-extinction: A Novel and Remarkable Case of Bio-objectification." Croatian Medical Journal 55: 423-7. doi:10.3325/ cmj.2014.55.423

Mayr, E. 1982. The Growth of Biological Thought. Diversity, Evolution, and Inheritance. Cambridge (MA): The Belknap Press of Harvard University Press.

Meikle, S. 1995. Aristotle's Economic Thought. Oxford: Oxford University Press.

Morell, V. 2016. "Rethinking the North American Wolf." Science 353: 434-435. doi: 10.1126/science.353.6298.434

Nicholls, H. 2008. "Let's Make a Mammoth." Nature 456: 310-14. 
Nuorteva, P. 1963. "Synanthropy of Blowflies (Dipt., Calliphoridae) in Finland." Annales Entomologici Fennici 29: 1-49.

Nuorteva, P. 1971. "The synanthropy of birds as an expression of the ecological cycle disorder caused by urbanization." Annales Zoologici Fennici 8: 547-553.

Oksanen M. Forthcoming. "Property." In Routledge Companion to Environmental Ethics, edited by B. Hale and A. Light. London: Routledge.

Oksanen, M. and H. Siipi (eds.). 2014. The Ethics of Animal Modification and Re-creation: Reviving, Rewilding, Restoring. Houndmills: Palgrave.

Ørebech, P. et al. 2005. The Role of Customary Law in Sustainable Development. Cambridge: Cambridge University Press.

Ostrom, E. 1990. Governing the Commons. The Evolution of Institutions for Collective Action. Cambridge: Cambridge University Press.

Quagga Project. 2015. http://www.quaggaproject.org. Accessed November 13, 2015.

Palmer, C. 2010. Animal Ethics in Context. New York: Columbia University Press.

Peterson, A.L. 2013. Being Animal: Beasts and Boundaries in Nature Ethics. New York: Columbia University Press.

Raup, D. M. 1991. Extinction. Bad Genes or Bad Luck? New York: W. W. Norton \& Company.

Reeves, R.G., J. A. Denton, F. Santucci, J. Bryk and F. A. Reed. 2012. "Scientific Standards and the Regulation of Genetically Modified Insects." PLoS Neglected Tropical Diseases 6(1): e1502. doi:10.1371/journal.pntd.0001502

Regan, T. 1988. The Case for Animal Rights. London: Routledge.

Russell, N. 2002. "The Wild Side of Animal Domestication." Society \& Animals 10: 285-302.

Shapiro, B. 2015. How to Clone a Mammoth. The Science of De-Extinction. Princeton: Princeton University Press.

Singer, P. 1979. Practical Ethics. Cambridge: Cambridge University Press.

Singer, P. 2010. "Let wild animals be wild." The Guardian, 8 March, 2010. https://www. theguardian.com/commentisfree/cif-green/2010/mar/08/wild-animals-captivityseaworld-orca. Accessed 2 September, 2016.

Strahorn, E.A. 2008. "Wildlife." In Oxford Encyclopedia of the Modern World, edited by P.N. Stearns. Oxford: Oxford University Press.

Summers-Smith, D. 1963. The House Sparrow. London: Collins.

Wilson, E.O. 1994. The Diversity of Life. Harmondsworth: Penguin.

Wong, K. 2016. “Neandertal Minds." Scientific American 25: 66-73. 
Yashina S., S. Gubin, S. Maksimovich, A. Yashina, E. Gakhova and D. Gilichinsky. 2012. "Regeneration of whole fertile plants from 30,000-y-old fruit tissue buried in Siberian permafrost." Proceedings of National Academy of Sciences 109: 4008-13. doi: 10.1073/pnas.1118386109 